\title{
Evaluation of Skin Prick Test Results In Patients With
}

\section{Atopic Dermatitis}

\author{
Ömer Kutlu ${ }^{1 *}$, Ahmet Metin $^{2}$ \\ ${ }^{1}$ Department of Dermatology and Venereology, Uşak University School of Medicine, Usak \\ ${ }^{2}$ Department of Dermatology and Venereology, Ankara Yuldirm Beyazıt University School of Medicine, Ankara
}

\begin{abstract}
Skin prick test (SPT) may be useful to detect possible intrinsic and extrinsic triggering factors for atopic dermatitis. In this study, it was aimed to examine patients with atopic dermatitis who underwent SPT. The most common triggering allergens were evaluated and the association between demographic factors, accompanying other allergic disorders and SPT positivity was also investigated. This study was carried out retrospectively by examining the file records of 144 patients who underwent SPT due to atopic dermatitis. The most frequent allergens with at least three positivity were grasses $(31.2 \%)$, grasses mix $(24.3 \%)$, Cynodon dactylon $(15.3 \%)$, D. pteronyssinus $(9.7 \%)$, D. farinae $(7.6 \%)$, respectively. D. farinae and D. pteronyssinus positivity were significantly statistically more frequent in patients with above 18 years than in patients under 18 years ( $\mathrm{p}$ values were 0.003 and 0.007 , respectively). There were statistically significant differences between at least one allergen positivity and allergic rhinitis $(\mathrm{p}=0.043)$ while there were no differences betwe en at least one allergen positivity and other allergic conditions including asthma, conjunctivitis, and food hypersensitivity $(0.721,0.927,0.258)$. The most common at least three positive allergens in patients with atopic dermatitis who had accompanyingal lergic rhinitis were grasses $(44.5 \%)$, grasses mix $(37.0 \%)$, Cynodon dactylon $(27.2 \%)$, D. farinae $(9.9 \%)$, D. pteronyssinus $(8.6 \%)$. In this study, house dust mites and grass allergens were found to be the most common triggers of atopic dermatitis. In conclusion, the frequency of food allergens was less common in atopic dermatitis. The most common allergic comorbidity associated with atopic dermatitis was allergic rhinitis, and house dust mites and grasses were the most common allergens in these cases.
\end{abstract}

Key Words: Allergy, atopic dermatitis, skin prick test

\section{Introduction}

Atopic dermatitis is a worldwide chronic inflammatory skin disease characterized by the presence of recurrent itching attacks and eczematous skin lesions. Atopic dermatitis may accompany other allergic diseases such as rhinitis, asthma, allergic conjunctivitis (1). The prevalence of atopic dermatitis is up to $20 \%$ in children while $3 \%$ in adults (2). Inflammatory reactions that develop as a result of immunological disorders in $\mathrm{T}$ cell functions under the influence of a number of triggering factors play an important role in the etiopathogenesis of atopic dermatitis in genetically susceptible individuals (3). Although atopic dermatitis is an antigen-dependent disease, exact allergens are not fully known. Aeroallergens and food-related allergens are among the triggering factors for atopic dermatitis (4).

Skin prick testing (SPT) is a method that shows an immediate IgE-mediated allergy. It is widely used across the world with a low risk of serious side effects $(5,6)$. Skin prick test may be useful to detect possible intrinsic and extrinsic triggering factors for atopic dermatitis (7).

In this study, records of patients with atopic dermatitis who underwent SPT were examined. The most common triggering allergens were evaluated and the association between demographic factors, accompanying other allergic disorders and SPT positivity was investigated.

\section{Material and Methods}

Study Design: The file records of 144 patients who underwentSPT due to atopic dermatitis in Kayseri Develi State Hospital between August 2018 and June 2019 were examined. The relationship between SPT and age ( $\geq 18$ years), gender, height, weight, accompanying allergic conditions including allergic rhinitis, food-related allergies, asthma was investigated. Patients with atopic dermatitis who had accompanying dermatographic urticaria and pregnancy were not included in this study. 


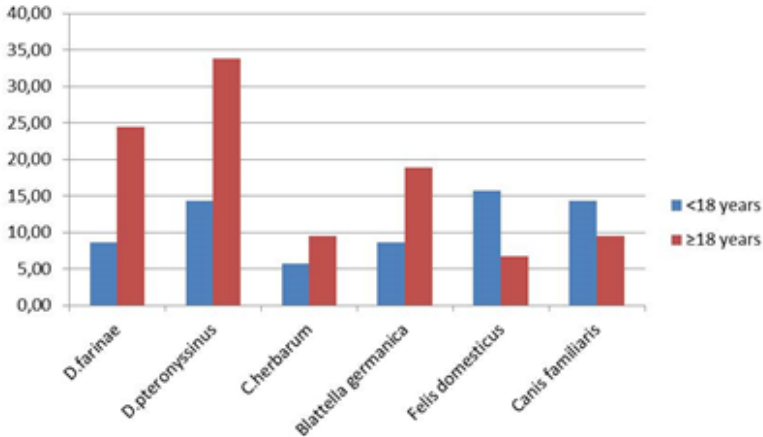

Fig.1. The comparison of the percentages of indoor allergens in terms of age

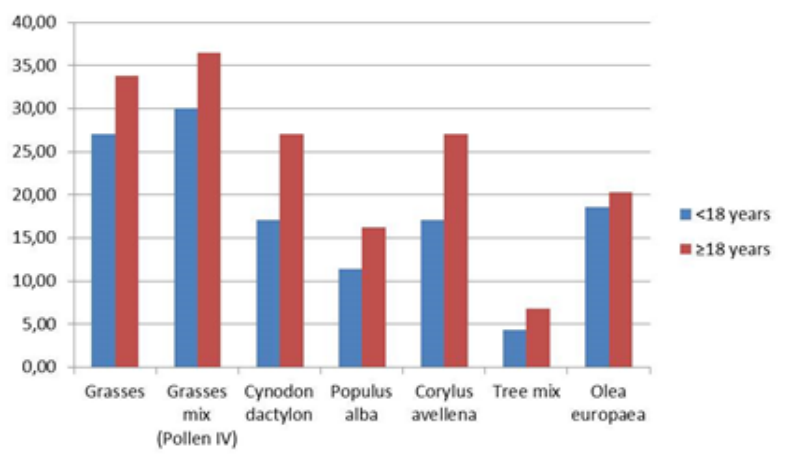

Fig.2. The comparison of the percentages of outdoor allergens in terms of age

Skin Prick Test Procedure and Interpretation: Skin prick tests were performed to patients with atopic dermatitisby the same dermatologist in order to achieve standardization using the ALK-Abello Prick Test (Horsholm, Denmark) solutions. After cleaning the volar surface of the forearms with alcohol, approximately equal numbers of allergens were applied to both arms, including six indoor, seven outdoor and six food allergens. Each allergen was dropped at $2 \mathrm{~cm}$ intervals to avoid overlapping reactions and false positivity. Histamine hydrochloride was used as a positive control and isotonic $\mathrm{NaCl}$ as a negative control. Allergens were classified into three categories as follows: (i) Indoor allergens; Dermatophagoides pteronyssinus (D. pteronyssinus), Dermatophagoides farinae (D. farinae), Cladosporium herbarum, Blattella germanica, Felis domesticus (F. domesticus), Canis familiaris (ii) Outdoor allergens; grasses (Dactylis, Festuca, Lolium, Phleum, Poa, Avena), grasses mix (Dactylis, Festuca, Lolium, Phleum, Poa, Avena), Cynodon dactylon, Corylus avellana, tree mix, Olea europaea and (iii) Food-related allergens; wheat flour, walnut, hazelnut, peanut, egg yolk, latex. Test result was evaluated after 15 minutes as follows: $1(+)$ erythema $\leq 15 \mathrm{~mm}$; no edema; $2(+)$ erythema $>15 \mathrm{~mm}$; edema $<3 \mathrm{~mm} ; 3$

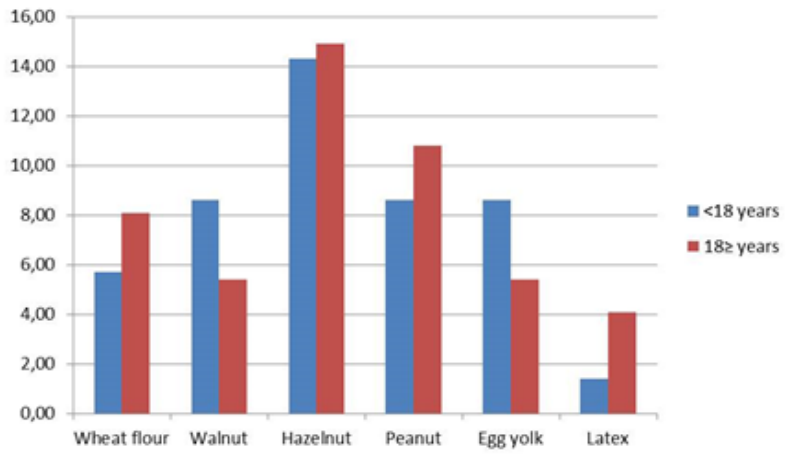

Fig.3. The comparison of the percentages of food allergens in terms of age

$(+)$ edema 3-6 mm; $4(+)$ edema as $>6 \mathrm{~mm}$ and pseudopod development (8). No serious complications were observed in any patient. The ethics committee approval was received from Erciyes University Ethics Committee, Kayseri, Turkey (approval date and number: 2019/770).

Statistical analysis: The data were analyzed using IBM SPSS Statistics for Windows, Version 20.00 (IBM Corp., Armonk, N.Y., USA).and a p value less than 0.05 was considered statistically significant. The normality of the data was tested. Continuous variables without normal distribution were expressed as the median. Categorical variables were analyzed by Pearson's Chi-square test.

\section{Results}

Demographic characteristics: A total of 144 patients with atopic dermatitis (106 females and 38 males) were included in this study. The median age of the patients was 18 (range 3-51) years. Ninetyone $(63.2 \%)$ patients had a family history of allergic diseases. The demographic characteristics of the patients are presented in table 1 (Table 1).

The most frequent allergens with at least three positivity were grasses $(31.2 \%)$, grasses mix (24,3\%), Cynodon dactylon (15.3\%), D. pteronyssinus $(9.7 \%), \mathrm{D}$. farinae $(7.6 \%), \mathrm{F}$. domesticus (7\%), and Olea europaea (5.6\%), respectively (Table 2 ).

\section{Skin Prick Test Results}

Skin prick test results in general: Ninety four $(65.3 \%)$ patients had at least one allergen positivity in SPT while $62(43.1 \%)$ had at least three positivity. Among the patients with at least one allergen positivity, 18 out of $4(19.2 \%)$ and with at least three allergen positivity, 13 out of 62 $(21.0 \%)$ had single allergen positivity. The SPT results in terms of the degree of allergen positivity are shown in table 2 (Table 2). 
Table 1. Demographic Characteristic of Patients With Atopic Dermatitis

\begin{tabular}{lc}
\hline Gender & $106(73.6 \%)$ \\
Female & $38(26.4 \%)$ \\
Male & $10(6.9 \%)$ \\
Occupation & $6(4.2 \%)$ \\
Officer & $1(0.7)$ \\
Worker & $86(59.7 \%)$ \\
Farmer & $11(7.6 \%)$ \\
Student & $30(20.8 \%)$ \\
Unemployed & \\
Housewife & $5(3.5 \%)$ \\
Education levels & $32(22.2 \%)$ \\
No literacy & $34(23.6 \%)$ \\
Primary school & $47(32.6 \%)$ \\
Middle School & $26(18.1 \%)$ \\
High school & \\
University & $36(25 \%)$ \\
Marital status & $108(75 \%)$ \\
Married & \\
Single & \\
Comorbid allergic conditions & $21(14.6 \%)$ \\
Asthma & $81(56.3 \%)$ \\
Allergic rhinitis & $25(17.4 \%)$ \\
Conjunctivitis & $8(5.6 \%)$ \\
Food hypersensitivity &
\end{tabular}

Skin prick test and gender: There were no statistically significant differences between the number of at least one/three allergen positivity and gender ( $\mathrm{p}$ values were $0.430,0.531$ respectively) (Table 3 ) and no statistically significant differences between each allergen positivity and gender $(\mathrm{p}>0.05)$.

Skin prick test and age: There was no statistically significant difference between at least one/three allergen positivity and under the age of 18 years ( $\mathrm{p}$ values were $0.143,0.291$ respectively).

D. farinae and D. pteronyssinus positivity were significantly statistically more frequent in patients above 18 years old than in patients under 18 years old ( $p$ values were 0.003 and 0.007 , respectively). On the other hand, there were no statistically significant differences between other allergens and the age of patients (Figure 1, 2, 3). While at least one allergen positivity was detected in $57.1 \%$ of the patients under the age of 18 years, it was detected in $68.9 \%$ of thepatients above $\geq 18$ years of age. There was at least three allergen positivity in $38.6 \%$ of the patients under the age of 18 whereas it was in $47.3 \%$ of the patients with $\geq 18$ years of age. There were no statistically significant differences between at least one/ three allergen positivity and age ( $\mathrm{p}$ values were $0.143,0.291$, respectively.)

Skin prick test and marital status: D. farinae and D. pteronyssinus positivity were statistically significantly more frequent in married patients than singles ( $p$ values were 0.004 and 0.007, respectively) (Table 4). There were no statistically significant differences between other allergens and marital status.

Skin prick test and occupations: There were statistically significant differences among occupations in terms of $\mathrm{D}$. farinae and $\mathrm{D}$. pteronyssinus positivity ( $\mathrm{p}$ values were 0.003 and 0.010 , respectively) (Table 5). There were no statistically significant differences between other allergens and occupations.

Skin test results andcomorbid allergic conditions: There was a statistically significant difference between at least one allergen positivity and allergic rhinitis $(p=0.043)$ while there was no statistically significant difference between at least one allergen positivity and other allergic conditions including 
Table 2. The Degrees of Allergen Positivity in Skin Prick Test

\begin{tabular}{|c|c|c|c|c|}
\hline \multirow[t]{2}{*}{ Type of allergens } & \multicolumn{4}{|c|}{ Number of patients (\%) } \\
\hline & $1+$ & $2+$ & $3+$ & $4+$ \\
\hline \multicolumn{5}{|l|}{ Indoor allergens } \\
\hline Dermatophagoides farinae & $1(0.7)$ & $12(8.3)$ & $11(7.6)$ & $0(0.0)$ \\
\hline Dermatophagoides pteronyssinus & $3(2.1)$ & $18(12.5)$ & $12(8.3)$ & $2(1.4)$ \\
\hline Cladosporium Herbarium & $1(0.7)$ & $10(6.9)$ & $0(0.0)$ & $0(0.0)$ \\
\hline Blattella Germanica & $1(0.7)$ & $13(9)$ & $3(2.1)$ & $3(2.1)$ \\
\hline Felis domesticus & $1(0.7)$ & $5(3.5)$ & $4(2.8)$ & $6(4.2)$ \\
\hline Canis familiaris & $0(0.0)$ & $10(6.9)$ & $4(2.8)$ & $3(2.1)$ \\
\hline \multicolumn{5}{|l|}{ Outdoor allergens } \\
\hline Grasses mix & $0(0.0)$ & $10(6.9)$ & $6(4.2)$ & $29(20.1)$ \\
\hline Grasses & $0(0.0)$ & $3(2.1)$ & $14(9.7)$ & $31(21.5)$ \\
\hline Cynodon dactylon & $1(0.7)$ & $9(6.3)$ & $5(3.5)$ & $17(11.8)$ \\
\hline Populus alba & $2(1.4)$ & $13(9.0)$ & $4(2.8)$ & $1(0.7)$ \\
\hline Corylus avellana & $0(0.0)$ & $1(0.7)$ & $1(0.7)$ & $0(0.0)$ \\
\hline Tree mix & $0(0.0)$ & $7(4.9)$ & $1(0.7)$ & $0(0.0)$ \\
\hline Olea europaea & $1(0.7)$ & $19(13.2)$ & $5(3.5)$ & $3(2.1)$ \\
\hline \multicolumn{5}{|l|}{ Food-related allergens } \\
\hline Wheat flour & $1(0.7)$ & $5(3.5)$ & $4(2.8)$ & $1(0.7)$ \\
\hline Walnut & $0(0.0)$ & $8(5.6)$ & $2(1.4)$ & $0(0.0)$ \\
\hline Hazelnut & $8(5.6)$ & $10(6.9)$ & $3(2.1)$ & $0(0.0)$ \\
\hline Peanut & $3(2.1)$ & $7(4.9)$ & $4(2.8)$ & $0(0.0)$ \\
\hline Egg yolk & $1(0.7)$ & $3(2.1)$ & $0(0.0)$ & $0(0.0)$ \\
\hline Latex & $1(0.7)$ & $3(2.1)$ & $1(0.7)$ & $0(0.0)$ \\
\hline
\end{tabular}

Table 3. The Differences Between Skin Prick Test Positivity and Gender

\begin{tabular}{lcccccc}
\hline \multirow{2}{*}{ Gender } & \multicolumn{2}{c}{$\begin{array}{c}\text { Number of at least one allergen } \\
\text { positivity }\end{array}$} & \multicolumn{2}{c}{ Number of three allergen positivity } \\
\cline { 2 - 7 } & Yes & No & P value & Yes & No & P value \\
\hline Female & $69(65.1 \%)$ & $37(34.9 \%)$ & & $44(41.5 \%)$ & $62(58.5 \%)$ & \\
Male & $22(57.9 \%)$ & $16(42.1 \%)$ & 0.430 & $18(47.4 \%)$ & $20(52.6 \%)$ & 0.531 \\
\hline
\end{tabular}

asthma, conjunctivitis, and food hypersensitivity (0.721, 0.927, 0.258, respectively).

There was a statistically significant difference between at least three allergen positivity and allergic rhinitis $(p=0.006)$. On the other hand, there was no significant difference between at least three allergen positivity and asthma, conjunctivitis, and food hypersensitivity (0.619, 0.583 , and 0.290 , respectively).

The number of patients with at least one and three allergen positivity was higher in those with allergic rhinitis.

The most common at least three positive allergens in patients with atopic dermatitis who had accompanying allergic rhinitis were grasses $(44.5 \%)$, grasses mix $(37.0 \%)$, Cynodon dactylon $(27.2 \%)$, D. farinae $(9.9 \%)$, D. pteronyssinus $(8.6 \%)$, and Canis familiaris $(8.6 \%)$.

\section{Discussion}

Detection of allergens, particularly in patients with atopic dermatitis, is crucial for the treatment and prevention of the disease $(6,7,9,10)$. Skin prick test is a fast, easy, and safe allergy test that can be performed to detect triggering allergens in patients with atopic dermatitis. It is reported that small papules under $3 \mathrm{~mm}$ of diameter are not significant for clinical studies. However, they are 
Table 4. The Differences Between bouse dust mite Positivity and Marital Status

\begin{tabular}{lcccccc}
\hline \multirow{2}{*}{ Marital status } & \multicolumn{2}{c}{ Number of D. pteronyssinus positivity } & \multicolumn{2}{c}{ Number of D. farinae positivity } \\
\cline { 2 - 6 } & Yes & No & P value & Yes & No & P value \\
\hline Married & $15(41.7 \%)$ & $32(58.3 \%)$ & \multirow{2}{*}{0.007} & $12(33.3 \%)$ & $24(66.7 \%)$ & \multirow{2}{*}{0.004} \\
Single & $20(18.5 \%)$ & $88(81.5 \%)$ & & $12(11.1 \%)$ & $96(88.9 \%)$ & \\
\hline
\end{tabular}

assumed to be positive in epidemiological based studies (11). In this study, unlike many other studies, we evaluated the percentages of papules both under and above three millimeters of diameter. In this regard, $65.3 \%$ of the patients had at least one allergen positivity while $43.1 \%$ had at least three allergen positivity. Yuksel et al. reported that $47 \%$ of children with atopic dermatitis had at least three millimeters of diameter positivity in SPT and Oğuz et al. reported with a similar percentage of allergen positivity in $52 \%$ of their patients $(12,13)$. On the other hand, Çölgeçen et al. reported that $24.4 \%$ of their patients with atopic dermatitis had at least three millimeters of diameter positivity in SPT while Kahraman et al. reported allergen positivity in $31.2 \%$ of their patients $(14,15)$.

Allergen factors in allergy-prone individuals that can change with geographical factors such as climate, vegetation, humidity, and altitude may cause different SPT results according to various studies. In this context, previous studies reported that the highest allergen positivity was pollen mix with a percentage of $70.3 \%$ for asthma in Erzurum, while grasses positivity was reported as $87.5 \%$ in Urfa $(16,17)$. In addition, it has been reported that house dust mite allergens were the most common allergens in patients with any allergic condition with a percentage of $51 \%$ in Antalya whereas grasses positivity was reported as $19.4 \%$ in Malatya $(15,18)$. Furthermore, Dikmen et al. reported that the most frequent allergen positivity was house dust mites $(41.3 \%)$ followed by grasses with a percentage of $18.2 \%$ in patients with any allergic condition (19). Different from most of previous studies, in our study, SPT was performed only to patients with atopic dermatitis. The most frequent allergens with $\geq 3 \mathrm{~mm}$ positivity were grasses, grasses mix, Cynodon dactylon, D. pteronyssinus, D. farinae, F. domesticus, and Olea europaea, respectively, in Kayseri Develi region. These results may indicate the importance of potentially triggering factors including indoor and outdoor allergens in patients atopic dermatitis, especially in Kayseri region.

In the present study, the percentage of grasses positivity was $31.2 \%$, while grasses mix positivity was $24.3 \%$. Aeroallergens was the most common allergen types in patients with atopic dermatitis. This finding was consistent with the results of previous SPT tests conducted in atopic dermatitis (20-22). Unlike grasses mix, grasses carry oat pollen, which is the type of grains known as Avena sativa has a different season. While the grasses season is spring-summer, the grain pollen season is all summer long. In this study, $6.9 \%$ of the cases had grasses positive/grass mix negative result which indicates the percentage of oat pollen allergy positivity. It can be proposed that in places where grains are common such as Develi region, test result may vary due to geographic differences. This point reveals the importance of geographic features in the SPT test.

In this study, C. dactylon positivity was $15.9 \%$ that indicates a large number of C. dactylon allergy in Kayseri, Develi region. There are numerous apple orchards in Kayseri, Develi. In this regard, Eşitmez et al. reported the frequency of Cynodon dactylon as $4.89 \%$ in apple orchards in Kayseri (23). In this context, apple orchards may be one of the potential culprit areas for patients with atopic dermatitis in Develi region.

Cat allergens transported on small particles are easily rendered airborne in the setting of normal ventilation (24). They can be easily moved by dresses, shoes, or human hair from cat-owning homes to environments, thus these allergies can also be transferred to cat non-owning homes (25). In Develi, which is a relatively rural place where cats are common, the interaction between children and cats and interaction among children are common. These may be related to frequency of cat allergies.

Olea europaea (olive tree) has a widespread distribution on the Aegean, Marmara, and Mediterranean regions in our country (26). A previous study revealed that the distribution of Olea europaea pollens density is about $0 \%$ in the Central Anatolian region including our area (27). However, in our study, the percentage of at least one positivity for Olea europaea was common with a percentage of $19.5 \%$ while the percentage of at least three positivity was $5.6 \%$. There is a strong migration from Marmara and Mediterranean regions to Develi, especially in summer months for holidays. It can be proposed 
Kutlu and Metin / Skin Prick Test Results and Atopic Dermatitis

Table 5. The Differences Between House Dust Mite Positivity and Occupations

\begin{tabular}{|c|c|c|c|c|c|c|}
\hline \multirow[t]{2}{*}{ Occupation } & \multicolumn{2}{|c|}{ D. farinae positivity } & \multirow[t]{2}{*}{$P$ value } & \multicolumn{2}{|c|}{ D. pteronyssinus positivity } & \multirow[t]{2}{*}{$P$ value } \\
\hline & Yes & No & & Yes & No & \\
\hline Officer & $4(40 \%)$ & $6(60 \%)$ & \multirow{6}{*}{0.003} & $3(30 \%)$ & $7(70 \%)$ & \multirow{6}{*}{0.010} \\
\hline Worker & $0(0 \%)$ & $6(100 \%)$ & & $1(16.7 \%)$ & $5(83.3 \%)$ & \\
\hline Farmer & $0(0 \%)$ & $1(100 \%)$ & & $1(100 \%)$ & $0(0 \%)$ & \\
\hline Student & $7(8.1 \%)$ & $79(91.9 \%)$ & & $13(15.1 \%)$ & $73(84.9 \%)$ & \\
\hline Unemployed & $2(18.2 \%)$ & $9(81.8 \%)$ & & $1(9.1 \%)$ & $10(90.9 \%)$ & \\
\hline Housewife & $11(36.7 \%)$ & $19(63.3 \%)$ & & $16(53.3 \%)$ & $14(56.7 \%)$ & \\
\hline
\end{tabular}

that both the immigrants and relatives who visited people in Kayseri, Develi may transport allergens and cause development of sensitivity to olive tree pollen. Furthermore, a cross-reaction can occur between the pollens of certain types of Oleaceae and Gramineae plant families and olive tree pollen (28). These two plant families which are present in Kayseri may be related to a high rate of olive tree pollen allergy.

In this study, we did not find a relationship between the positivity of allergens and gender. However, the positivity of D. pteronyssinus and D. farinae were notably more common in females than males. These two allergens were significantly higher in patients with marriage, above 18 years of age as well as housewives. The high frequency of allergen positivity in patients above 18 years of age and married patients may be related to the high frequency of housewives. House dust mites are more common in humid environments, and less in place with dry and hot temperatures. They live in carpets and furniture and in environments with optimum conditions such as humidity as approximately $75 \%$ and a temperature of $25^{\circ} \mathrm{C}$. Laboratory studies have reported that the survival of D. pteronyssinus that can live ten days is $73 \%$ relative humidity and at $25{ }^{\circ} \mathrm{C}$. D. farinae disappears in $35 \%$ relative humidity effectively at $22{ }^{\circ} \mathrm{C}$ (29-31). Months with the highest relative humidity, which is a suitable condition for house dust mite living in Develi are December, January, and February (32). It can be concluded that house dust mites may be an important factor for atopic dermatitis exacerbation during the winter months. In addition, environmental protection for indoor allergens are to keep the humidity low, prevent wet areas on walls and carpets, and keep the home temperature at high degree during the winter. These are crucial measures to prevent aggravation of atopic dermatitis.

Dikmen et al. reported that grass and tree pollen positivity was more common at an early age, while house dust mites positivity was more common in advanced ages (19). Escarrer et al. conducted a study with 64 atopic dermatitis patients and reported that patients under 2 years of age had more common food-related allergy while patients between ages of 2-10 years had more common food as well as aeroallergens-related allergy and patients above 10 years of age had more common aeroallergens-related allergy (33). In our study, aeroallergen positivity except for cats and dogs were higher in patients under 18 years of age than patients above 18 years of age. On the other hand, food allergens did not contain any standardized results. With our results, it can be suggested that questioning possible animal contact in patients with atopic dermatitis under 18 years of age can be useful in reducing disease exacerbations.

In previous reports, egg, soybean, and milk have been reported as the most common reason for food-related allergy in patients with atopic dermatitis. In various studies, the prevalence of eggs was reported above $70 \%$, soybean $3.1 \%$ to $33.3 \%$, and milk $33.3 \%$ to $50 \%(34-37)$. In this study, the frequency of food-related allergens was less than indoor and outdoor allergens. The most common at least three positivity food allergen was wheat flour with a percentage of $3.5 \%$. This result may be related to the fact that SPT is more significant in respiratory allergies than in foodrelated allergies. This can also be related to the occurrence of secondary allergens of food-related allergens during their passage through the digestive tract. In addition, the age of the patients in this study includes adults as well as children. Given the fact that food allergen positivity is more common in children, it can be understood why the frequency of food allergens is low in overall study population.

In the present study, the most common accompanying allergic disease to atopic dermatitis was allergic rhinitis. The SPT positivity was statistically significantly more common in patients 
with accompanying allergic rhinitis than those without allergic rhinitis. In contrast, there were no significant differences between SPT positivity in patients with accompanying asthma, conjunctivitis, and food hypersensitivity and those without these allergic diseases. Aeroallergens were the most common allergens in patients accompanied by allergic rhinitis.

This study has some limitations. SPT was performed using certain allergens. Cross-reactivity between the certain tested allergens may have partially changed results, especially for foodrelated allergens. Single-center results may limit the generalisability of the findings.

In this study, house dust mites and grass allergens were the most common triggers of atopic dermatitis. The frequency of food allergens was less common in atopic dermatitis. The most common allergic comorbidity associated with atopic dermatitis was allergic rhinitis, and house dust mites and grasses were the most common allergens in these cases. Further multicenter, comprehensive SPT based studies on atopic dermatitis will illuminate the possible triggers of the disease in atopic dermatitis in different geographies.

\section{References}

1. Leung DY, Boguniewicz M, Howell MD, Nomura I, Hamid QA. New insights into atopic dermatitis. J Clin Invest 2004; 113: 651 657.

2. Nutten S. Atopic dermatitis: global epidemiology and risk factors. Ann Nutr Metab 2015; 66: 8-16.

3. Van Reijsen F, Bruijnzeel-Koomen C, et al. Skin-derived aeroallergen-specific T-cell clones of Th2 phenotype in patients with atopic dermatitis. J Allergy Clin Immunol 1992; 90: 184-193.

4. Spergel JM. From atopic dermatitis to asthma: the atopic march. Ann Allergy Asthma Immunol 2010; 105: 99-106.

5. Cox L, Williams B, Sicherer S,et al. Pearls and pitfalls of allergy diagnostic testing: report from the American college of allergy, asthma and immunology/American academy of allergy, asthma and immunology specific $\operatorname{IgE}$ test task force. Ann Allergy Asthma Immunol 2008; 101: 580-592.

6. Heinzerling L, Mari A, Bergmann K-C, Bresciani M, Burbach G, Darsow U, et al. The skin prick test-European standards. Clin Trans1 Allergy 2013; 3: 1-10.
7. Kim TE, Park SW, Noh GW, Lee SS. Comparison of skin prick test results between crude allergen extracts from foods and commercial allergen extracts in atopic dermatitis by double-blind placebo-controlled food challenge for milk, egg, and soybean. Yonsei Med J 2002; 43: 613-20.

8. http://turkdermatoloji.org.tr/icerik/detay/10 2

9. Türkmen D, Altunışık N. Malatya İlinde 169 Alerjik Kontakt Dermatitli Hastada Yama Testi Sonuçları. Turkiye Klinikleri J Dermatol 2018; 28: 114-122.

10. Kutlu Ö, Temiz SA. Examination of the frequency of patients with pre-diagnosed allergic contact dermatitis attending dermatology outpatient clinics and evaluation of patch test results.Ann Med Res.2020. doi: 10.5455/annalsmedres.2020.07.728

11. Bousquet J, Heinzerling L, Bachert C,et al. Practical guide to skin prick tests in allergy to aeroallergens. Allergy. 2012; 67: 18-24.

12. Yuksel H, Can D, Reisli İ,et al. Characteristics and prognosis of childhood atopic dermatitis: a multicenter study in Turkey. Int Arch Allergy Immunol 2010; 152: 362-367.

13. Oğuz ID, Hızlı Ö, Akşan B. Giresun Bölgesi Deri Prick Testi Sonuçlarının Kapsamlı Analizi. Konuralp Medical Journal 2019; 11: 295-301.

14. Çölgecen E, Özyurt K, İntepe Y, et al. Yozgat yöresinde atopik semptomlu hastalarda deri prick testi sonuçlar1. J Clin Exp Invest 2014; 5: 64-68.

15. Kahraman H, Kılıç T, Sucaklı MH. The evaluation of prick test results in Malatya. J Clin Anal Med 2015; 6: 4-7.

16. Mirici A, Girgiç M, Tutar Ü, Kaynar H, Sağlam L, Gürgüner M. Erzurum'da astımlı hastalarda atopi sıklığı. Akciğer Arşivi 2001; 2: 64-68.

17. Ceylan E. Şanlıurfa'da bronş astımlı olguların klinik özellikleri. Solunum 2003; 6: 5-13.

18. Yalçın A, Öncel S, Akcan A, Eravșar K, Polat $\mathrm{HH}$, Terzioğlu E. Prevalence of allergic asthma, rhinitis and conjunctivitis in over 16year-old individuals in Antalya.

Turkiye Klinikleri J Med Sci 2010; 30: 888894.

19. Dikmen N, Bozkuş F, Bilgiç HK. Kahramanmaraş ilinde allerjik yakınmalar ile başvuran hastaların deri prick testi sonuçlarının değerlendirilmesi. Tepecik Eğit ve Araşt Hast Dergisi 2017; 27: 109-113.

20. Baykan A, Baykan H. Atopik dermatitli hastalarda deri prick test ve spesifik Ig E sonuçlarının değerlendirilmesi. Duzce Medical Journal 2017; 19: 19-26. 
21. Ayvaz A, Baki A, Gedik Y. Doğu karadeniz bölgesindeki çocuklardaallerji deri testi (skin prick test) sonuçlar1. Turkiye Klinikleri J AllergyAsthma 2003; $5: 80-84$.

22. Kiymet B, Güvenç U, Cordan Yazıc1 A, Köktürk A, İkizoğlu, Taşdelen B. Mersin'de Atopi ve Deri Hastalıkları. Turkiye Klinikleri J Dermatol 2007; 17: 105-111.

23. Eşitmez B, Doğan I. Kayseri ili elma bahçelerinde görülen yabanc1 ot türlerinin belirlenmesi. Meyve Bilimi 2016; 3 :1-9.

24. Liccardi G, D'Amato G, Russo M, Canonica GW, D'Amato L, De Martino M, et al. Focus on cat allergen (Fel d 1): Immunological and aerodynamic characteristics, modality of airway sensitization and avoidance strategies. Int Arch Allergy Immunol 2003; 132: 1-12.

25. Çetinkaya F, Birben E, Kalayci C. Cat Allergens in Homes of Cat Allergic Children without a Cat. Insights Allergy Asthma Bronchitis. 2015;1:2.

26. Işık N, Doğanlar S, Frary A.Genetic Diversity of Turkish Olive Varieties Assessed by Simple Sequence Repeat and Sequence-Related Amplifi ed Polymorphism Markers. Plant Genet Resour 2011; 51:1646-1654.

27. B1çakç1 A, Tosunoğlu A. Allergenic Pollens in Turkey. Asthma Allergy Immunol 2019; 17: 724.

28. Gonzalez E, Villalba M, Rodriguez R. Allergenic cross-reactivity of olive pollen. Allergy 2000; 55: 658-663.

29. Arlian LG, Platts-Mills TA. The biology of dust mites and the remediation of mite allergens in allergic disease. J Allergy Clin Immunol 2001; 107: S406-S13.

30. Arlian LG, Neal JS, Vyszenski-Moher DL. Reducing relative humidity to control the house dust mite Dermatophagoides farinae. J Allergy Clin Immunol 1999; 104: 852-856.

31. Arlian LG. Dehydration and survival of the European house dust mite, Dermatophagoides pteronyssinus. J Med Entomol 1975; 12: 437 442.

32. https://www.worldweatheronline.com/develiweather/kayseri/tr.aspx

33. Escarrer JM, Muñoz-López F. Role of aeroallergens in the etiopathogenesis of atopic dermatitis. Allergol Immunopath 2002; 30: 126.

34. Sampson HA, Ho DG. Relationship between food-specific $\operatorname{IgE}$ concentrations and the risk of positive food challenges in children and adolescents. J Allergy Clin Immunol 1997; 100: 444-451.

35. Burks AW, James JM, Hiegel A, Wilson G, Wheeler JG, Jones SM, et al. Atopic dermatitis and food hypersensitivity reactions. J Pediatr 1998; 132: 132-136.

36. Van Bever H, Docx M, Stevens W. Food and food additives in severe atopic dermatitis. Allergy 1989; 44: 588-594.

37. Magnolfi C, Zani G, Lacava L, Patria M, Bardare M. Soy allergy in atopic children. Ann Allergy Asthma Immunol 1996; 77: $197-$ 201. 